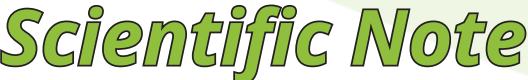

\section{The use of crotalaria as possible indirect agent to control Aedes aegypti L. (Diptera: Culicidae)}

\author{
Barbara Clara Schneider ${ }^{\oplus}$, Adriana Maria Meneghetti \& Denise Lange $^{\bowtie(b)}$
}

Universidade Tecnológica Federal do Paraná, Santa Helena, Brazil.

EntomoBrasilis 13: e859 (2020)

\author{
Edited by: \\ William Costa Rodrigues \\ Article History: \\ Received: 07.vi.2019 \\ Accepted: 18.iv.2020 \\ Published: 02.vii.2020

\section{Corresponding author: \\ Denise Lange \\ 乃 deniselange@yahoo.com.br} \\ Funding agencies: \\ Without funding declared
}

\begin{abstract}
Aedes aegypti L. (Diptera: Culicidae) is a vector of arboviruses associated with dengue, chikungunya, zika and yellow fever. Based on empirical knowledge, plants belonging to genus Crotalaria (Fabaceae) attract dragonflies, which are the main natural predator to A. aegypti and help controlling populations of this mosquito. The aim of the present study is to investigate (i) whether Crotalaria is a food source for A. aegypti and (ii) whether Crotalaria attracts predators to this mosquito, mainly dragonflies. The study was carried out from January to March 2018 in two Crotalaria spectabilis Roth (Fabaceae) cultivation areas, which covered $100 \mathrm{~m}^{2}$ (each) in Missal County, Paraná State, Brazil. Samples of all arthropods foraging on C. spectabilis were collected. Observations in situ were carried out to investigate whether $A$. aegypti individuals visit $C$. spectabilis flowers. In total, 14,967 arthropods were recorded foraging on C. spectabilis (288 in cultivation area 1 and 14,679 in cultivation area 2). Dragonflies and damselflies were recorded foraging on C. spectabilis crops, but no $A$. aegypti individual was recorded in active collections and observations in situ. These results indicate that $C$. spectabilis works as food source and/or place used by several arthropods to find preys. The incidence of dragonflies and damselflies flying in C. spectabilis monocultures indicates that these plants attract dragonflies, as well as that Crotalaria can help indirectly controlling A. aegypti populations.
\end{abstract}

Keywords: Anisoptera; Biological control; Crotalaria spectabilis; Dragonflies; Mosquito vectors.

\begin{abstract}
$\triangle$ edes aegypti Linnaeus (Diptera: Culicidae) is an insect species native to Africa, which has wide geographical distribution (COSTA 2001) due to the rapid growth of human populations and urbanization of tropical areas that lack basic sanitation infrastructure (BRASIL 2008). Adult Aedes aegypti individuals feed on both floral nectar and fruit juice (COSTA 2001). Only females suck blood, which is essential for egg maturation (Consolı \& Oliveira 1994). Overall, female culicids lay eggs after each blood meal (Consoli \& OLIVEIRA 1994). According to BARATA et al. (2001), female A. aegypti individuals feed more than once between two successive ovipositions, which increases their likelihood of ingesting and transmitting viruses. This mosquito is capable of transmitting dengue, as well as other arboviruses such as chikungunya, zika and yellow fever (Gomes 2016). Zika infection has received significant attention due to severe sequelae, such as microcephaly, observed in newborn babies. According to the World Health Organization (WHO), it is necessary interrupting the humanvector contact in order to prevent and, consequently, reduce the transmission of these arboviruses. Thus, a collective effort comprising health professionals, managers and the population is necessary to help controlling these diseases (BRASIL 2009a, b).
\end{abstract}

Nowadays, the mechanical method is the main way to control mosquito vectors of arboviruses, since it focuses on directly eliminating both the vector and breeding sites by eliminating standing and uncapped water containers (ZARA et al. 2016). The use of chemicals, such as larvicides (based on Pyriproxyfen) and insecticides aimed at controlling adult insects (IOC 2016), is an alternative control method adopted by Ministério da Saúde.
According to empirical knowledge, Crotalaria (Fabaceae) plants enable the biological control of $A$. aegyppti because they supply floral resources to adult mosquitos and attract dragonflies (their predator). Some Brazilian cities, such as Dourados-MS, Missal-PR and Uberaba-MG, have encouraged the population to grown crotalaria plants in order to help the biological control of $A$. aegypti. Adult dragonflies live two months, on average, after spending approximately five years in water. These efficient predators have a chewing mouthpiece that enables them to eat $14 \%$ of their weight (GULLAN \& CRANSTON 2012). They are polyphagous, since they feed on flies, bees, beetles, wasps, mosquitos and other dragonflies (Costa et al. 2012). The peak of adult dragonflies' foraging activity in search of prey happens in the hottest hours of the day (HAMADA et al. 2014). Dragonflies lay eggs in the same preferred locations as dengue mosquitos do (i.e., clean water). Hatched nymphs can prey on A. aegypti larvae and act as natural mosquito-population controllers (SEBASTIAN et al. 1980; MiURA \& TAKAHASHI 1988; SATHe \& Bhusnar 2010).

Crotalaria genus has approximately 600 species distributed in the tropics and subtropics, mainly in the Southern hemisphere, most of them are observed in Africa. This genus has 30 native and 11 exotic species registered in Brazil (Flores et al. 2016). Plant species belonging to this genus have considerable plasticity and are capable of adapting to different environmental conditions. Crotalaria can grow in several habitat types, such as areas close to rivers, coastal hills, sandbanks, edge of forests, fields and savannahs. They are opportunistic, quite common in altered places such as roadsides, and culture invaders (FLORES \& MıOTTO 2005).

Crotalaria is mainly used in agriculture because it is not very 
demanding in terms of soil fertility; besides, it has great potential to be used for biological nitrogen fixation, as well as presents rapid growth and the ability to reduce the levels of some soil nematode species (SILVEIRA \& RaVA 2004). It is also used to produce green manure, mulch and soil cover to help no-tillage systems (SILVEIRA \& RAVA 2004).

The aim of the current study was to investigate whether Crotalaria spectabilis Roth is a food source for $A$. aegypti and, consequently, attracts predators such as dragonflies. Thus, the use of crotalaria could help controlling $A$. aegypti populations.

The study was conducted in Missal County, PR, interspersed in two areas of $100 \mathrm{~m}^{2}$ (area 1: $25^{\circ} 02^{\prime} 39.2^{\prime \prime} \mathrm{S}$ and $54^{\circ} 20^{\prime} 43.6^{\prime \prime}$ W; area 2: $25^{\circ} 05^{\prime} 51.9^{\prime \prime} \mathrm{S}$ and 54 $4^{\circ} 14^{\prime} 49^{\prime \prime} \mathrm{W}$ ) located $12 \mathrm{~km}$ apart from each other. Area 1 was 400 m away from Itaipu Lake, whereas area 2 was $160 \mathrm{~m}$ from the municipal artificial lake of Missal County.

Crotalaria spectabilis was planted in October 2017, in both areas. The procedure was manually performed based on the following parameters: $25-\mathrm{cm}$ spacing between rows (deposition of 20 seeds per linear meter), 20-cm spacing between plants, and three centimeters down the ground. Data were collected during plants' reproductive period, i.e., from January to March 2018.

Sugar concentration (sucrose equivalents in ${ }^{\circ}$ Brix) in the nectar of $C$. spectabilis flowers was analyzed through refractometry, in manual refractometer (Eclipse ${ }^{\circledR}$ ) equipped with graduated microcapillaries of $10 \mu \mathrm{L}$. In total, 80 flower buds were bagged in "voil" type fabric bags in the late afternoon; nectar was collected at 7:00 am in the following morning, in the evaluated areas. Eight samples comprising the nectar of 10 flowers were collected.

Floral visitors' behavior was monitored from January to March 2018, based on visual observations in situ of threemonth-old plants. Ten (10) newly opened flowers from 10 plants (one flower per plant) located one meter apart from each other were analyzed in each area. These plants were marked with string and numbered with tape. Observations took place for two consecutive days from 7:00 am to 2:00 pm, in 5-minute sessions per hour, on each flower. After five minutes of observation on the first flower, the next flower was monitored to enable observing visitations for another five minutes; this procedure was repeated until completing the observation of 10 flowers per hour, whose floral visitors were recorded.

Active arthropod collections (SISBIO n. 50733-4) were carried out on sunny days free from excessive wind by one individual who used an entomological net. Two zigzag sweeps were carried out in the two investigated areas for one day, from 8:00 am to 3:00 pm, in 10-minute sessions per hour, after seven days of floral visitor observations. This time was selected for observations in situ based on the time flowers open (early morning) and close (in the afternoon). All collected arthropods were killed using "câmeras mortíferas" and, later, they were placed in containers, labeled and stored in alcohol (70\%) at Laboratório de Biologia e Ecologia de Insetos at Universidade Tecnológica Federal do Paraná, Santa Helena Campus. Taxonomic identification took place at family level, based on taxonomic keys described by Rafael et al. (2012).

The number of dragonflies foraging on C. spectabilis plants was counted "by the naked eye" in 10-minute sessions per hour, for three days. It was done from 11:00 am to 03:00 $\mathrm{pm}$, which is the time of greatest solar irradiation that, in its turn, is an important resource for the thermoregulation and increased foraging activity of individuals belonging to this insect group (DE MARCO 1998).

Crotalaria spectabilis flowers produced nectar with sugar concentration of $30.5 \pm 7.46 \%$ in Brix (mean \pm standard deviation) at mean temperature of $28{ }^{\circ} \mathrm{C}$. The volume of nectar could not be measured with the aid of a microcapillary tubes due to the small amount of it.

In total, 14,967 arthropods (288 in area 1 and 14,679 in area 2) were captured (Table 1). These arthropods belonged to 10 orders, 41 families and 93 morphospecies. No A. aegypti or other Culicidae individuals were seen/collected during flower observations in situ and in active collections performed with entomological net.

Area 1 had 137 arthropods visiting C. spectabilis flowers and area 2 had 277. Coleoptera was the order presenting the highest abundance of individuals visiting flowers - 36 individuals in area 1 and 96 in area 2. Floral visitor Xylocopa frontalis (Oliver) (Hymenoptera: Anthophoridae) was identified in situ in the two evaluated areas. Trigona spinipes (Fabricius) (Hymenoptera: Apidae) was observed only in area 2 while it was visiting C. spectabilis flowers ( $n=93$ individuals).

Forty-five (45) and 28 dragonflies have visited C. spectabilis in areas 2 and 1, respectively. During active collections, 22 dragonflies were collected in area 2, although no individual was collected in area 1. Besides the Coenagrionidae individuals captured in active collections, individuals belonging to other families, including the ones belonging to suborder Anisoptera, were seen in observations in situ. However, they could not be identified.

Adult $A$. aegypti individuals did not forage on crotalaria in the two evaluated areas. On the other hand, odonates were found in active collections (area 2) and in observations conducted in both areas.

The lack of $A$. aegypti in the evaluated $C$. spectabilis monoculture areas can be explained by the small amount of nectar produced by these plants. The current study has made attempts to collect and chemically analyze the nectar; however, the volume of floral nectar produced by $C$. spectabilis was insufficient to be individually collected with microcapillary tubes and syringes. According to MARQUES et al. (2013), the individual volume of nectar in C. spectabilis flowers was too small to be measured; thus, it was necessary using the nectar of more flowers in order to measure sugar concentration in it. Sugar concentration of $30 \%$ (in Brix scale) in the solutions collected from 10 flowers in the current study was lower than that recorded by MARQUES et al. (2013) in Botucatu County-SP; they found mean sugar concentration of $51.3 \%$ (in Brix scale) in C. spectabilis and stated that the floral nectar of this species presents sugar concentrations higher than that of other species acknowledged as honeybearing plants, such as Vernonia polysphaera (Spreng.) Less. (Asteraceae), Grevillea robusta Cunn. (Proteaceae) and Antigonon leptopus Hook. \& Arn. (Polygonaceae).

Another factor that could explain the lack of $A$. aegypti in $C$. spectabilis lies on the biology of the mosquito. According to SouzA (2015), adult A. aegypti individuals that have access to nectar under natural conditions eat carbohydrates in the first $48 \mathrm{~h}$ after pupal phase emergence. Therefore, it is likely that the evaluation period in the present study has coincided with the period when adults did not have carbohydrate deficit, i.e., when individuals in these mosquito populations undergo a developmental stage that does not require flower nectar. However, Rizzı et al. (2017) have evaluated the biological cycle of $A$. aegypti in Cascavel County, PR, and found that, in the period of greatest intensity of $A$. aegypti, the number of individuals increases in the hottest and most humid months 
Table 1. Number of morphospecies, number of individuals, relative frequency (\%) and feending habits of arthropods collected in two areas planted with Crotalaria spectabilis in Missal County, PR, from January to March 2018.

\begin{tabular}{|c|c|c|c|c|c|c|c|c|}
\hline \multirow[t]{2}{*}{ Order } & \multirow[t]{2}{*}{ Family } & \multicolumn{2}{|c|}{$\begin{array}{c}\text { Number of } \\
\text { morphospecies }\end{array}$} & \multicolumn{2}{|c|}{ Number of individuals } & \multicolumn{2}{|c|}{ Relative frenquency (\%) } & \multirow{2}{*}{$\begin{array}{c}\text { Feending } \\
\text { habits }\end{array}$} \\
\hline & & Area 1 & Area 2 & Area 1 & Area 2 & Area 1 & Area 2 & \\
\hline \multirow{8}{*}{ Coleoptera } & Lagriidae & 1 & - & 2 & - & 0.88 & - & Herb. \\
\hline & Curculionidae & 2 & - & 2 & - & 1.77 & - & Herb. \\
\hline & Chrysomelidae & 4 & 2 & 46 & 141 & 7.08 & 4.17 & Herb. \\
\hline & Coccinellidae & - & 1 & - & 4 & - & 1.04 & Pred. \\
\hline & Carabidae & 1 & - & 1 & - & 0.88 & - & Pred. \\
\hline & Cantharidae & - & 1 & - & 2 & - & 0.52 & Omn. \\
\hline & Lycidae & - & 1 & - & 3 & - & 1.04 & Herb. \\
\hline & other & 2 & 2 & 1 & 1 & 0.88 & 0.52 & - \\
\hline \multirow{10}{*}{ Hemiptera } & Nabidae & 2 & 2 & 5 & 35 & 1.77 & 3.13 & Pred. \\
\hline & Reduviidae & - & 2 & - & 4 & - & 1.04 & Pred. \\
\hline & Lygaeidae & - & 1 & - & 2 & - & 0.52 & Herb. \\
\hline & Delphacidae & 2 & 1 & 3 & 2 & 1.77 & 0.52 & Herb. \\
\hline & Pentatomidae & 1 & 4 & 15 & 94 & 4.42 & 4.17 & Herb. \\
\hline & Coreidae & 3 & 2 & 7 & 2 & 1.77 & 0.52 & Herb. \\
\hline & Cercopidae & - & 1 & - & 2 & - & 0.52 & Herb. \\
\hline & Miridae & - & 1 & - & 13,775 & - & 4.17 & Herb. \\
\hline & Cicadellidae & 1 & - & 2 & - & 1.77 & - & Herb. \\
\hline & other & - & 1 & - & 1 & - & 0.52 & - \\
\hline \multirow{7}{*}{ Diptera } & Muscidae & 1 & 1 & 26 & 47 & 5.30 & 4.17 & Nec. \\
\hline & Syrphidae & 1 & 1 & 1 & 14 & 0.88 & 2.60 & Pred. \\
\hline & Tephritidae & 1 & 1 & 32 & 44 & 5.30 & 3.65 & Herb. \\
\hline & Dolichopodidae & 1 & 1 & 7 & 32 & 1.77 & 3.65 & Pred. \\
\hline & Sciaridae & 2 & 2 & 4 & 20 & 0.88 & 2.60 & Nec. \\
\hline & Calliphoridae & 1 & 1 & 6 & 46 & 2.65 & 3.65 & Herb. \\
\hline & other & 7 & 7 & 33 & 105 & 19.56 & 12.50 & - \\
\hline \multirow[t]{5}{*}{ Lepidoptera } & Crambidae & 1 & 1 & 23 & 11 & 7.08 & 1.56 & Herb. \\
\hline & Nymphalidae & - & 1 & - & 1 & - & 0.52 & Herb. \\
\hline & Pyralidae & 1 & 1 & 13 & 18 & 4.42 & 3.65 & Herb. \\
\hline & Noctuidae & 1 & 2 & 9 & 12 & 3.54 & 3.65 & Herb. \\
\hline & other & 1 & 1 & 2 & 1 & 1.77 & 0.52 & - \\
\hline \multirow{13}{*}{ Hymenoptera } & Vespidae & 3 & 2 & 3 & 30 & 1.77 & 4.17 & Pred. \\
\hline & Ichneumonidae & 2 & 1 & 6 & 4 & 1.77 & 1.04 & Paras. \\
\hline & Evaniidae & 2 & 4 & 4 & 12 & 1.77 & 2.60 & Paras. \\
\hline & Formicidae & 1 & 1 & 1 & 7 & 0.88 & 1.04 & Omn. \\
\hline & Apidae & 1 & 2 & 1 & 111 & - & 4.17 & Herb. \\
\hline & Anthophoridae & 1 & 1 & 1 & 1 & 0.88 & 0.52 & Herb. \\
\hline & Braconidae & 1 & 1 & 2 & 1 & 0.88 & 0.52 & Paras. \\
\hline & Pompilidae & 1 & 1 & 1 & 1 & 0.88 & 0.52 & Pred. \\
\hline & Halictidae & 1 & - & 1 & - & 0.88 & - & Herb. \\
\hline & Chalcididae & - & 1 & - & 2 & - & 1.04 & Paras. \\
\hline & Scoliidae & 1 & 1 & 2 & 2 & 1.77 & 0.52 & Paras. \\
\hline & Sphecidae & - & 2 & - & 2 & - & 1.04 & Paras. \\
\hline & other & 3 & 4 & 8 & 24 & 5.30 & 5.73 & - \\
\hline Mantodea & - & - & 1 & - & 2 & - & - & - \\
\hline Odonata & Coenagrionidae & - & 1 & - & 22 & - & 2.60 & Pred. \\
\hline Orthoptera & Tettigoniidae & - & 2 & - & 10 & - & 2.60 & Herb. \\
\hline Dermaptera & Forficulidae & - & 1 & - & 6 & - & 2.60 & Pred. \\
\hline \multirow[t]{2}{*}{ Araneae } & - & 1 & 1 & 18 & 23 & 7.08 & 4.17 & Pred. \\
\hline & Total & 55 & 69 & 288 & 14,679 & 100 & 100 & - \\
\hline
\end{tabular}

Legend: Pred=Predator; Herb= Herbivore; Paras=Parasitoid; Omn= Omnivore; Nec= Necrophagous (sensu Rafael et al. 2012).

of the year, i.e., between spring and summer, which is the time when the present study was carried out. This outcome reinforced the idea that lack of $A$. aegypti individuals in crotalaria flowers may have resulted from low floral nectar attractiveness.

Although $A$. aegypti was not found in crotalaria plants, odonates were observed in both evaluated areas; they were mostly abundant in area 2 . This outcome can be explained by the distance between areas and the nearest waterbodies - area 2 was closer to a waterbody than area 1. According to COSTA et al. (2012), odonates are often seen close to waterbodies due to their biological dependence on them. Females oviposit inside the stems of aquatic plants, in submerged plant debris or throw their eggs directly into the water.

The highest adult odonate density is often recorded in the summer or during floods, whereas the lowest density or total lack of it is often recorded in winter or during drought periods (Bıschof et al. 2013; DıJKSTRA et al. 2014). The present study was carried out in the summer, which is the time of the year when adult odonates are most abundant. Thus, the greater the abundance of odonate individuals, the greater 
the intraspecific competition for food.

Since $C$. spectabilis monoculture attracted several arthropods, mainly herbivores, predators (including dragonflies) found an additional place to search for food in these areas. Increased prey capture can favor the maintenance and even the increase of predator populations. Since dragonflies prey on Aedes spp. adults and larvae, and since both species use freshwater bodies to reproduce, increased dragonfly populations would lead to increased number of nymphs, a fact that could help controlling $A$. aegypti populations due to larval predation by dragonfly species. According to SATHE \& Bhusnar (2010), dragonfly nymphs are polyphagous and efficient in preying on mosquito larvae - they are even capable of preying on immature Aedes spp. Thus, it is possible suggesting that crotalaria crops may have indirect action in the biological control of $A$. aegypti by attracting odonates, which are natural enemies to insects belonging to genus Aedes (Figure 1).

The current study recorded lesser abundance of arthropods in area 1 than in area 2 . Area 1 is located in the rural area of the investigated city and it has great amounts of other

plants (secondary forest and fruit trees) around it, such as soybean crops and the Permanent Preservation Area (PPA) (APP) of Itaipu Lake. These sites can provide more niches for arthropods. On the other hand, area 2 is located in the urban region of Missal County, whose nearby area is not rich in other plants other than grass. Thus, the current hypothesis is that $C$. spectabilis grown in area 2 has greater abundance of floral visitors than that grown in area 1.

Results in the current study have shown that C. spectabilis acts as food source for several arthropods. However, it is not possible stating that crotalaria can act in the natural control of $A$. aegypti, since it attracts them due to the food resource found in its flowers. Thus, it may act as a "trap plant", which attracts arthropods and their likely natural enemies. On the other hand, the incidence of odonates in C. spectabilis monoculture areas close to water sources indicates the presence of predators, which can help controlling A. aegypti populations in these places.

\section{ACKNOWLEDGMENT}

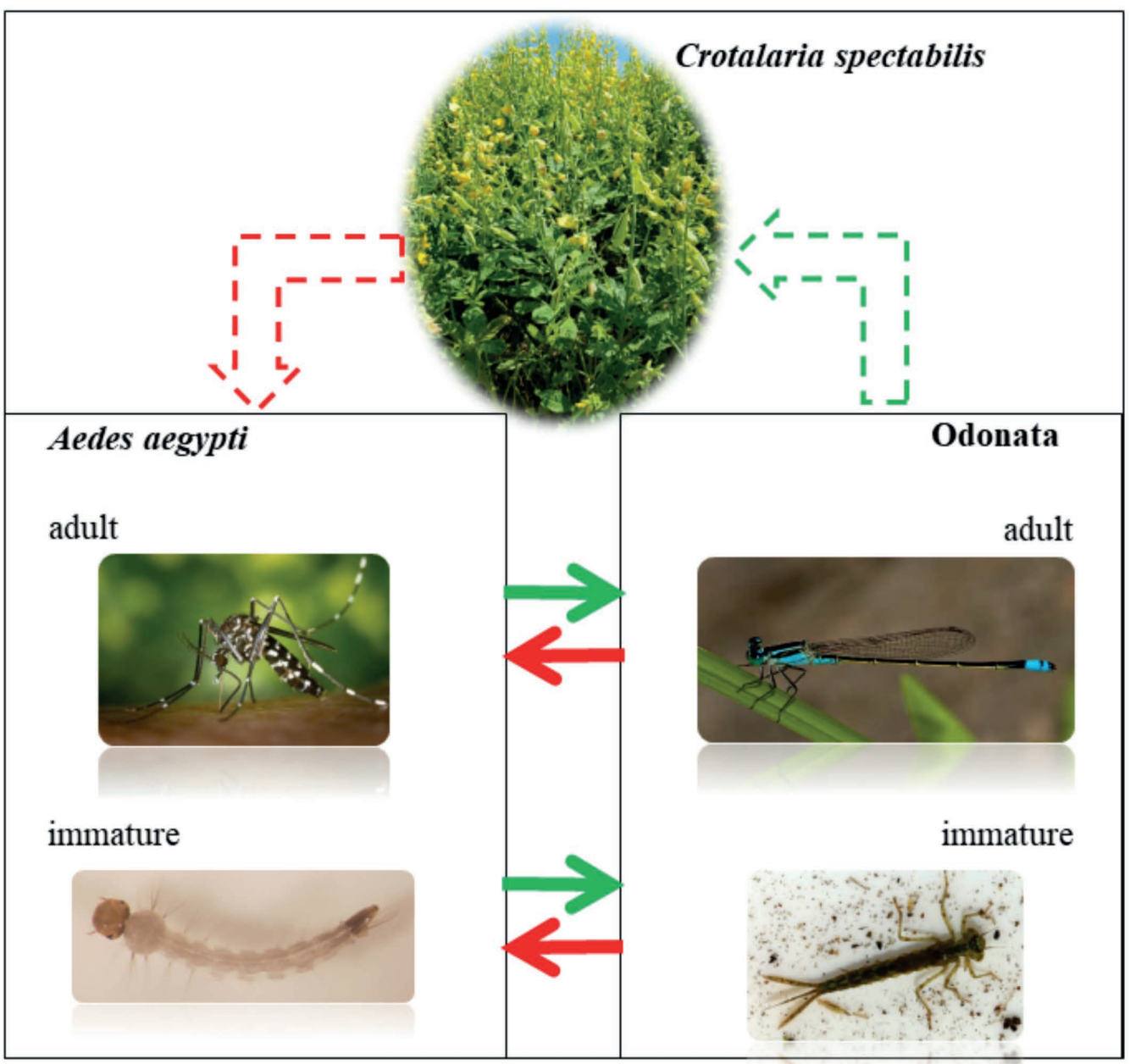

Figure 1. Schematics showing crotalaria-Aedes-odonatas interaction. Dotted arrows represent indirect relationships; arrows with continuous stroke represent direct relationships; red arrows represent negative relationships; and green arrows, positive relationships. Source of photos: Aedes aegypti immature - Econt; adult Aedes aegypti individual - https://www.gazetaonline.com.br; odonata immature: CJ Sharp; adult odonata and Crotalaria spectabilis - B.C. Schneider.

The authors are grateful to E.A.B. and Silva for correcting the text, as well as to D.S. Alves for helping identify arthropods and correcting the text. The authors also thank Universidade Tecnológica Federal do Paraná for providing the infrastructure for the current study.

\section{REFERENCES}

Barata, EF, AIP Costa, FC Neto, CM Glasser, JMS Barata \& D Natal, 2001. População de Aedes aegypti Linnaeus em área endêmica de dengue, Sudeste do Brasil. Revista Saúde Pública, 35: 237-42. DOI: https://doi.org/10.1590/s003489102001000300004

Barreto, AC \& MF Fernandes, 2001. Recomendações técnicas para o uso da adubação verde em solos de Tabuleiros Costeiros. Acre: Embrapa Tabuleiros Costeiros (Circular 
Técnica, 19).

Bischof, MM, MA Hanson, MR Fulton, RK Kolka, SD Sebestyen \& MG Butler, 2013. Invertebrate community patterns in seasonal ponds in Minnesota, USA: Response to Hydrologic and Environmental Variability, 33: 245-256. DOI: https://doi.org/10.14393/BJ-v32n2a2016-30491.

Brasil, 2008. Ministério da Saúde. Secretaria de Atenção à Saúde. Departamento de Atenção Básica. Vigilância em Saúde: Dengue, Esquistossomose, Hanseníase, Malária, Tracoma e Tuberculose / Ministério da Saúde, Secretaria de Atenção à Saúde, Departamento de Atenção Básica. $2^{a}$ edição.

Brasil, 2009a. Ministério da Saúde. Secretaria de Vigilância em Saúde. Departamento de Vigilância Epidemiológica. Diretrizes nacionais para prevenção e controle de epidemias de dengue / Ministério da Saúde, Secretaria de Vigilância em Saúde, Departamento de Vigilância Epidemiológica.

Brasil, 2009b. Ministério da Saúde. Secretaria de Vigilância em Saúde. Secretaria de Atenção à Saúde. O agente comunitário de saúde no controle da dengue / Ministério da Saúde, Secretaria de Vigilância em Saúde.

Consoli, RAGB \& RL Oliveira, 1994. Principais mosquitos de importância sanitária no Brasil. $20^{\mathrm{a}}$ ed. Rio de Janeiro: Fiocruz.

Costa, JM, TC Santos \& BB Oldrini, 2012. Odonata Fabricius, 1792, pp. 245-256. In: Rafael, JA, GAR Melo, CJB de Carvalho, SA Casari \& R Constantino (Eds.). Insetos do Brasil: Diversidade e Taxonomia. Ribeirão Preto, Holos Editora.

Costa, M, 2001. Ocorrência do Aedes aegypti na Região Noroeste do Paraná: um estudo sobre a epidemia da dengue em Paranavaí - 1999, na perspectiva da Geografia Médica. Dissertation (Master in Geography). Universidade Estadual Paulista, Faculdade Estadual de Educação Ciências e Letras de Paranavaí, Presidente Prudente.

De Marco, PJ, 1998. The Amazonian Campina dragonfly assemblage: patterns in microhabitat use and behaviour in a foraging habitat (Anisoptera). Odonatologica, 27: 239248.

Dijkstra, KDB, MT Monaghan \& SU Pauls, 2014. Freshwater biodiversity and aquatic insect diversification. Annual Review of Entomology, 59: 143-163. DOI: https://doi.org/10.1146/annurev-ento-011613-161958

Flores, AS, MDL Wanderley, GJ Shepherd, TS Melhem, AM Giulietti \& SE Martins, 2016. Crotalária. Flora Fanerogâmica do Estado de São Paulo, São Paulo, Instituto de Botânica, 8: 174-187.

Flores, SF \& ST Miotto, 2005. Aspectos fitogeográficos das espécies de Crotalaria L. (Leguminosae: Faboideae) na Região Sul do Brasil. Acta Botânica Brasileira, 19: 245-249. DOI: https://doi.org/10.1590/s0102-33062005000200006

Gomes, FBC, 2016. Aedes aegypti: Consultoria Legislativa da Câmara dos Deputados. Estudo Técnico. Available

\section{Suggestion citation:}

Schneider, BC, AM Meneghetti \& D Lange, 2020. The use of crotalaria as possible indirect agent to control Aedes aegypti L. (Diptera: Culicidae). EntomoBrasilis, 13: e859.

Available in: doi: 10.12741/ebrasilis.v13.e859 in: <https://www2.camara.leg.br/camaranoticias/ radio/materias/COM-A-PALAVRA/511643-FIQUE-PORDENTRO:-ESTUDO-DA-CAMARA-SE-APROFUNDA-NOTEMA-\%E2\%80\%9CAEDES-AEGYPTI\%E2\%80\%9D.html>. [Accessed on: 13.iv. 2020].

Gullan, PJ \& PS Cranston, 2012. Os insetos: um resumo de entomologia. $4^{a}$ Ed. São Paulo, Roca.

Hamada, N, JL Nessimian \& RB Querino, 2014. Insetos aquáticos na Amazônia brasileira: taxonomia, biologia e ecologia. Manaus, INPA.

IOC (Instituto Oswaldo Cruz) 2016. Considerações técnicas sobre a aplicação aérea de inseticidas em área urbana. Rio de Janeiro: Fiocruz (Nota Técnica, 4).

Marques, APS, RCR Camargo, KS Malagodi-Braga, EO ONO \& MA Urchei, 2013. Avaliação do potencial melífero e polinífero de Crotalaria juncea L. e Crotalaria spectabilis Roth. (Fabaceae, Papilionoideae). Cadernos de Agroecologia, 8, 1-4. Available in: <http://revistas.abaagroecologia.org.br/index.php/cad/article/view/15036> [Accessed on: 13.iv.2020].

Miura, T \& R Takahashi, 1988. A laboratory study of predation of damselfly larvae, Enallagma civile, upon mosquito larvae Culex tarsalis. Journal of the American Mosquito Control Association, 4: 129-131.

Rafael, JA, GAR Melo, CJB de Carvalho, SA Casari \& $R$ Constantino, 2012. Insetos do Brasil: Diversidade e Taxonomia. Ribeirão Preto, Holos Editora.

Rizzi, CB, RL Rizzi, PV Pramiu, E Hoffmann \& CT Codeço, 2017. Considerações sobre a dengue e variáveis de importância à infestação por Aedes aegypti. Revista Brasileira de Geografia Médica e da Saúde, 13: 24-40.

Sathe, TV \& AR Bhusnar, 2010. Biodiversity of mosquitovorous dragonflies (Order: Odonata) from Kolhapur district including Western Ghats. Biological Forum-An International Journal, 2: 38-41.

Sebastian, A, MM Thu, M Kyaw \& MM Sein, 1980. The use of dragonfly larvae in the control of Aedes aegypti. Southeast Asian Journal of Tropical Medicine and Public Health, 11: 104-107.

Silveira, PM \& CA Rava, 2004. Utilização de crotalária no controle de nematóides da raiz do feijoeiro. Santo Antônio de Goiás: Embrapa Arroz e Feijão (Comunicado Técnico, 74).

Souza, RM, 2015. Efeito do néctar de diferentes espécies vegetais na longevidade e oviposição de Aedes (Stegomyia) aegypti (Linnaeus, 1762). Dissertation (Master in Animal Biology). Universidade Federal do Mato Grosso do Sul, Campo Grande.

Zara, ALSA, SM Santos, ESF Oliveira, RG Carvalho \& GE Coelho, 2016. Estratégias de controle do Aedes aegypti: uma revisão. Epidemiologia e Serviços de Saúde, 25: 391-404. DOI: https://doi.org/10.5123/S1679-49742016000200017

$* * * * * * * * * *$
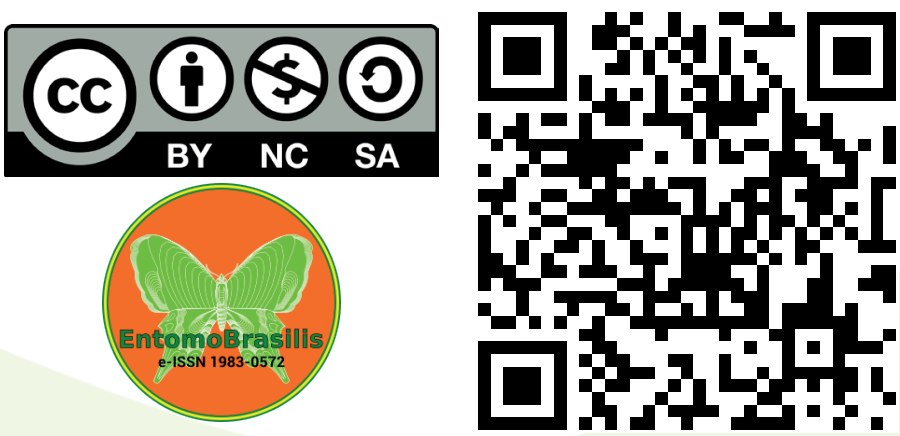